\title{
Prevalence and Associated Factors of Depression among Prisoners in Jimma Town Prison, South West Ethiopia
}

\author{
Zakir Abdu $\left(\mathbb{D},{ }^{1}\right.$ Teshome Kabeta $\left(\mathbb{D},{ }^{2}\right.$ Lamessa Dube $\mathbb{D}^{2}$, \\ Workinesh Tessema, ${ }^{3}$ and Mubarek Abera ${ }^{3}$ \\ ${ }^{1}$ Department of Psychiatry, Faculty of Public Health and Medical Sciences, Mettu University, Ethiopia \\ ${ }^{2}$ Department of Epidemiology, Faculty of Public Health, Institute of Health, Jimma University, Ethiopia \\ ${ }^{3}$ Department of Psychiatry, Faculty Medical Sciences, Institute of Health, Jimma University, Ethiopia
}

Correspondence should be addressed to Zakir Abdu; zakirabdu45@gmail.com

Received 3 November 2017; Revised 15 January 2018; Accepted 18 April 2018; Published 19 June 2018

Academic Editor: Arif Khan

Copyright (C) 2018 Zakir Abdu et al. This is an open access article distributed under the Creative Commons Attribution License, which permits unrestricted use, distribution, and reproduction in any medium, provided the original work is properly cited.

\begin{abstract}
Background. Mental disorder is one of the greatest challenges that current and future generations will face. Currently among all people suffering from depression, $85 \%$ of them live in low- and middle-income countries. Previous studies reported the global burden/prevalence of depression to be five to ten times higher among prisoners than the general population. However, the prevalence of depression among prisoners in our study area is not known. Objective. This study therefore aimed to assess the prevalence and associated factors of depression among prisoners in Jimma town in 2017. Method. A cross-sectional study design was employed on 332 prisoners selected by systematic random sampling method. Data was collected by a face to face interview using Beck Depression Inventory (BDI-II) scale. Data analysis was done using SPSS version 20. Result. The study revealed that $41.9 \%(n=139)$ of participants among prisoners had depression. Having family history of mental illness $(\mathrm{AOR}=6.05,95 \% \mathrm{CI}=$ $2.6,13.8)$, having chronic physical illness $(\mathrm{AOR}=2.87,95 \% \mathrm{CI}=1.29,6.41)$, having history of previous incarceration $(\mathrm{AOR}=3.26$, $95 \% \mathrm{CI}=1.02,10.64)$, lack of job in the prison $(\mathrm{AOR}=4.96,95 \% \mathrm{CI}=2.09,11.8)$, lifetime alcohol use $(\mathrm{AOR}=3.61,95 \% \mathrm{CI}=1.8$, 7.26), thinking life to be a difficult one after release from prison ( $\mathrm{AOR}=2.07,95 \% \mathrm{CI}=1.2,3.6)$, having age between 21 and 25 years $(\mathrm{AOR}=2.04,95 \% \mathrm{CI}=1.06,3.89)$, and having poor social support $(\mathrm{AOR}=2.2,95 \% \mathrm{CI}=1.27,3.82)$ had significant association with depression in the fully adjusted final regression model. Conclusion. This study has shown that the prevalence of depression among prisoners was very high. Having family history of mental illness, having chronic physical illness, having previous incarceration, lack of job in prison, lifetime alcohol use, thinking life to be difficult one after release from prison, having age between 21 and 25 years old, and having poor social support were found to have an impact on the prevalence of depression.
\end{abstract}

\section{Background}

Mental disorder impose an enormous disease burden almost everywhere across the world [1]. It is one of the greatest challenges that the current and future generations will face [2]. Depression is the most common and severe but treatable mental disorder [3]. Out of people suffering from depression; $85 \%$ live in low- and middle-income countries [4]. When compared to the general population, worldwide, prisoners were five to ten times more likely to develop depression $[5,6]$.

The incidence of mental disorders among prisoners in the western countries reported that one from seven prisoners suffers from some type of psychiatric disorder and depression is the most one [6]. According to a systematic review from 24 western countries, $10.2 \%$ of male prisoners and $14.1 \%$ of female prisoners had depression [7]. From prison in United States (US), about $23 \%$ of state prisoners and $30 \%$ of jail imprisonments were found to have depression [8]. Prevalence of depression among prisoners in Asian country is more than two times higher than the western countries [9] but lower than the result in African [10]. According to studies conducted in different parts of Africa, $10.4 \%$ to $82.5 \%$ of the prisoners found to be depressed and the disorder is higher among females and young age groups [11-13]. One study from sub-Saharan country showed that the magnitude of depression among prisoners is $42.2 \%$ and the more affected 
group is the lower educational status and singles [10, 14]. Little is known in east Africa, and one study which is done recently in Ethiopia revealed that at least eight prisoners out of nineteen suffered from depression and it was associated with residence of prisoners [5].

Most studies done in prisons of different countries across the world revealed the following factors. Being female $[6,7$, $15-18]$, older age $[14,19]$, performing work in prison (AOR = 0.49 , CI $0.28-0.87$ ), prisoners incarcerated repeatedly (AOR: 3.3, CI 1.7-6.3) [7, 20, 21], having past psychiatric history (OR: 1.9, CI 1.4-25) [21, 22], having family history of mental illness (AOR: 1.6, CI: (1.0-2.7)) [21], having history of previous substances used (AOR: 3, CI: 2.3, 4.0) [21], having poor social support [AOR: 0.62; CI 0.44, 0.89], and thinking life to be a difficult one after release from prison (AOR: 1.87, CI 1.30, 2.69) [5] were variables identified as they had association with depression.

\section{Methods and Materials}

An institutional based cross-sectional study was conducted from June 1 to June 15, 2017. All prisoners in Jimma town prison were included. Those prisoners who were not able to communicate because of any kind of illness were excluded from study. And those prisoners openly imprisoned were excluded.

To get maximum sample size, prevalence rate $(P)$ of $50 \%$ was taken. Single population proportion formula was used to determine sample size at 95\% CI and 5\% marginal error.

$$
n_{i}=\frac{(z \dot{\alpha} / 2)^{2} \times p(1-p)}{d^{2}}
$$

where

$n_{i}$ is initial sample size;

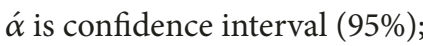

$p$ is estimated proportion which was assumed to be $50 \%$ (0.5);

$d$ is margin of sampling error tolerated (5\%).

$$
\begin{aligned}
n_{i} & =\frac{(1.96)^{2} \times 0.5(1-0.5)}{(0.05)^{2}}=\frac{3.8416 \times 0.5 \times 0.5}{0.0025} \\
& =384
\end{aligned}
$$

The total number of prisoners in Jimma town Correctional Institution is 1460 which is less than 10,000. Using finite population correction formula the final sample size was

$$
n_{f}=\frac{n_{i}}{1+n_{i} / N}
$$

where

$$
\begin{aligned}
& n_{f} \text { is final sample size; } \\
& n_{i} \text { is initial sample size calculated above (384); }
\end{aligned}
$$

$N$ is total number of prisoners (1460).

$$
\begin{aligned}
n_{f} & =\frac{384}{1+384 / 1460} \\
& \Longrightarrow \frac{384}{1.259}=\mathbf{3 0 5}
\end{aligned}
$$

Considering nonrespondent subjects and by adding $10 \%$ nonresponse rates the final number of the study subject became 336.

A systematic random sampling was done using the prisoners list and using the sampling interval size calculated using the formula

$$
\frac{N}{n}=k
$$

where $N$ is the total population (1460) and $n$ is sample size (336) while $k$ is sampling interval size. $K=$ (approximately 4). Therefore, every 4 th prisoners on the list was selected. List prisoners from 1 to 1460 and then randomly select a number between 1 and 4 (e.g., "2"):

(i) 1 st person selected $=$ the 2 nd on the list;

(ii) 2 nd person selected $=2+4$, the 6 th, etc.

Data was collected using structured questionnaire by face to face interview technique. BDI-II was used to screen the presence and absence of depression [23]. The Oslo 3-item social support scale was used to assess level of social support $[24,25]$.

2.1. Operational Definition. Figure 1 shows the factors associated with depression among prisoners in Jimma town: sociodemographic (like age, sex, religion, m. status, ethnicity, residence), substance (like alcohol, khat, cigarette, cannabis/shisha/ganja), socioeconomic factors (like income, occupation, education status, having children), clinical related factors (like heart disease, diabetic mellitus, hypertension, epilepsy, past mental illness, family history of mental illness), and prison environment related factors (like previous incarceration, duration of incarceration, acceptance of crime penalized for, thinking life after released from prison is difficult, type of criminality, practicing religion, work in prison, social support).

Figure 2 shows the prevalence of depression: 43 (13.0\%) had mild depression, 66 (19.9\%) had moderate depression, and $30(9.0 \%)$ had severe depression. About 44 (13.2\%) of participants were without depression (normal) and 149 (44.9\%) had borderline clinical depression.

According to BDI-II, depressed are participants who score 14 and more, while those who score 13 or lower are not depressed. From depressed participants, those who score 14-19 are mildly depressed, 20-28 are moderately depressed, and 29-69 are severely depressed.

Those thinking life to be a difficult one after release from prison are participants who believe that their life will not go as before being incarcerated when they become released from prison. It was assessed by a developed questionnaire which is a set of attitudes that generated a single score. 


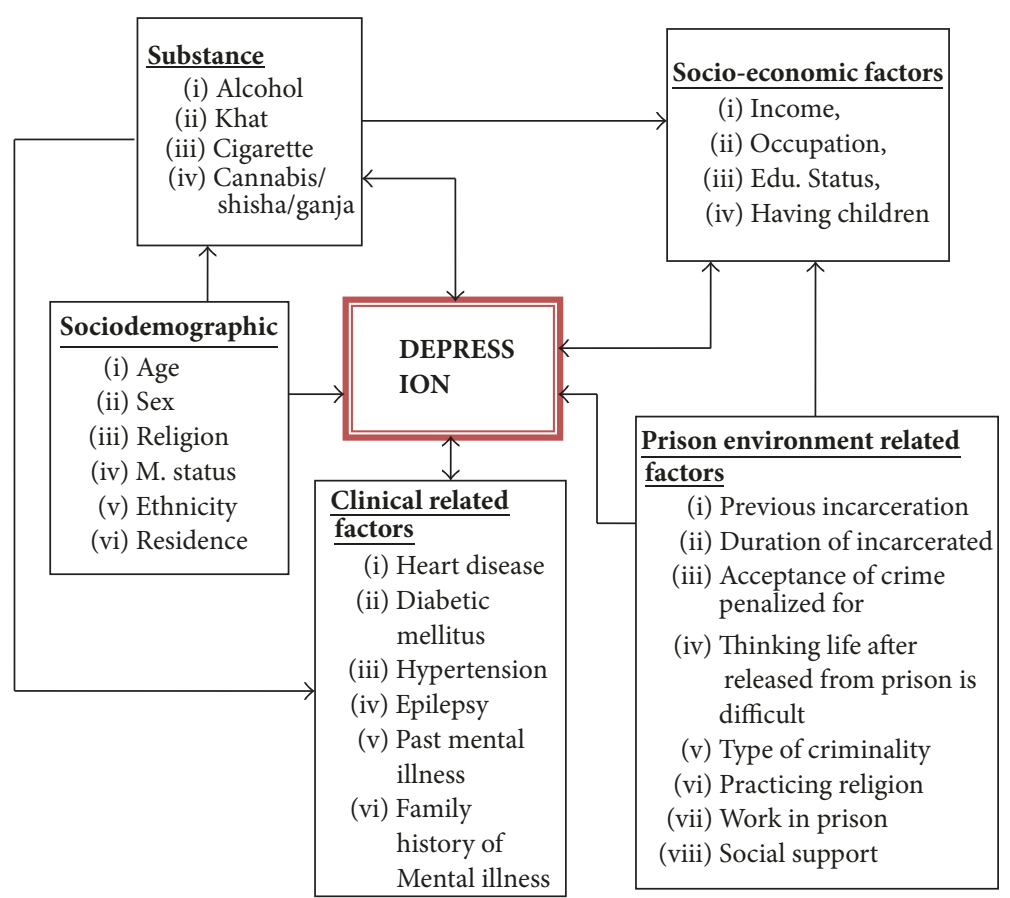

FIGURE 1: Conceptual framework of study on prevalence of depression and associated factors among prisoners in Jimma town Correctional Institution, South West Ethiopia, 2017 (source: developed by the principal investigator by reviewing literatures and scientific background).

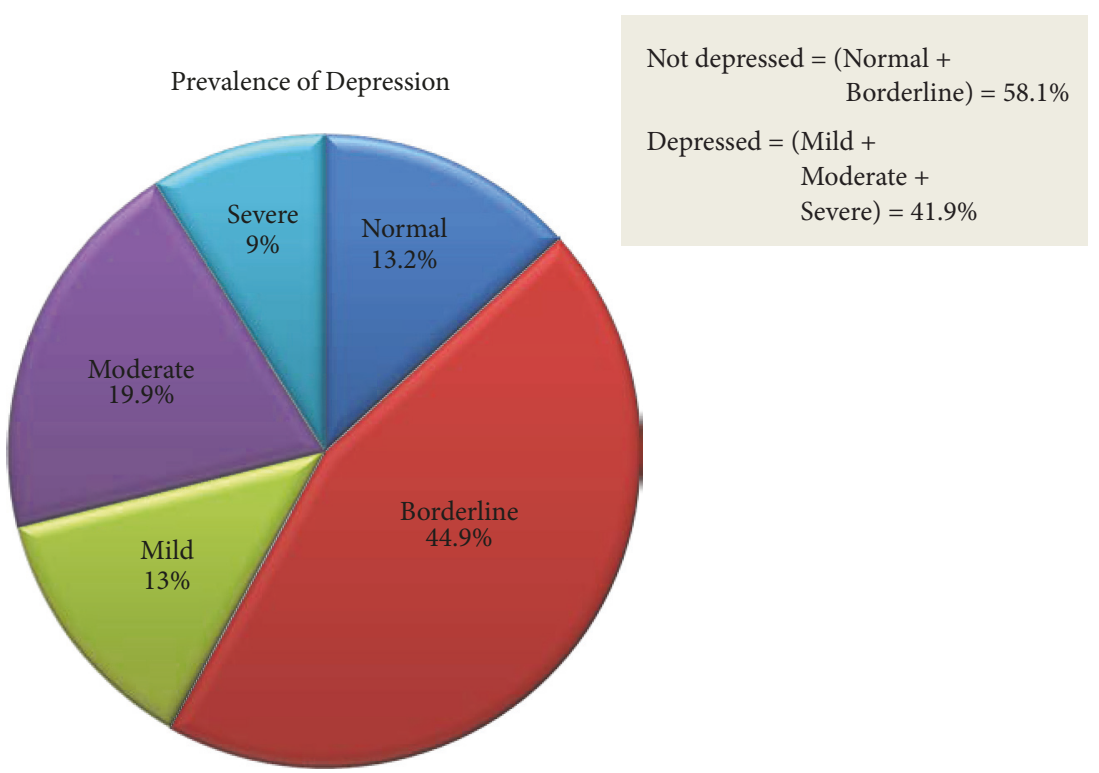

FIGURE 2: Levels of depression and its prevalence among prisoners in Jimma town Correctional Institution, June, 2017. $N=332$.

There are also participants with chronic illness, illness that can be managed but cannot be cured, and having a greater risk of developing depression, for example, heart diseases, diabetic mellitus, HIV/AIDS, past mental illness, etc. And the response for chronic illness is from self-report of the participants.

Those accepting penalty for their crime are participants who accept the fact that the reason why he/she was incarcerated was because of doing that crime. It was assessed by generating a single score.
2.2. Data Analysis. Data was analyzed using SPSS version 20.0. Binary and multivariable logistic regression analyses were employed. The variables which have a statistical significance association in the final multivariable analysis were identified on the basis of $p$ values $<0.05$ and AOR with $95 \%$ confidence intervals.

Ethical Approval and Consent of Participants. The study was conducted after ethical clearance is obtained from ethical review board of Jimma University (IHRPGC/761/2017). 
Confidentiality was ensured and all related questions they raised were answered. Participation was completely voluntary, with no economic or other motivation, and each participant signed written informed consent for their participation. Participants right to refuse or discontinue participation at any time they want was strictly respected.

\section{Result}

3.1. Sociodemographic and Economic Characteristics. From the total of 336 participants, 332 were interviewed. Among 332 prisoners participating, the majority were males, 311 (93.7\%). The median age of the respondents was 26 years with an interquartile range of 12 years (Table 1 ).

3.2. Prison Related Environment Related. The study revealed that one in twelve $(8.4 \%)$ of participants had history of previous incarceration. More than one-fourth (27.4\%) of them stayed for $<4$ months in prison and the median time spent in prison was 10 months with an interquartile range of 20 months. About 7/16th (44.9\%) thought that life might be difficult after release from prison. About one-fifth (19.0\%) of respondents had work opportunities within the prison of whom 23 (6.9\%) engaged in wood work. About half (50.9\%) of respondents reported having poor social support

3.3. Clinical Factors Characteristics. The study revealed that about one-sixth (16\%) of respondents had chronic physical illness. One in every eleven (9\%) of the respondents had history of past mental illness (Table 2).

3.4. Prevalence of Depression. The prevalence of depression among prisoners in Jimma town prison over the past couple of weeks was found to be $41.9 \%$ (three in every seven) with a $95 \%$ CI and $36.7-46.7 \%$. Of the total number of participants $13 \%$ had mild, $20 \%$ had moderate, and $9 \%$ had severe depression. About 44 (13.2\%) of participants were found to have no depression (normal) and 149 (44.9\%) had borderline clinical depression.

3.5. Factors Associated with Depression. Socioeconomic and prison environment characteristics of respondents like marital status, residence before incarceration, occupation, educational status, having children, duration of stay in prison, acceptance for the charge of crime, and opportunity to pray in prison did not show association with depression in the bivariate analysis. However, being female, being in the age group between 21 and 25 years, previous history of incarceration, thinking life to be a difficult experience after release from prison, lack of opportunity for job in the prison, type of criminality, presence of family member with mental illness, presence of chronic physical illness, past mental illness, and poor social support were associated with depression in the bivariate analysis (Table 3 ).

Regarding lifetime substance use bivariate analysis indicated that lifetime alcohol use, smoking cigarette, chewing khat and cannabis/shisha/ganja use were associated with depression and entered multivariate logistic regression model.
TABLE 1: Background characteristics of study participants among prisoners in Jimma town prison, South West Ethiopia, June 2017 $(N=332)$.

\begin{tabular}{|c|c|c|}
\hline Study variables & Frequency $(N)$ & Percentage (\%) \\
\hline \multicolumn{3}{|l|}{ Gender } \\
\hline Male & 311 & 93.7 \\
\hline Female & 21 & 6.3 \\
\hline \multicolumn{3}{|l|}{ Age } \\
\hline $18-20$ & 82 & 24.7 \\
\hline $21-25$ & 78 & 23.5 \\
\hline $26-34$ & 90 & 27.1 \\
\hline$>34$ & 82 & 24.7 \\
\hline \multicolumn{3}{|l|}{ Marital status } \\
\hline Married & 132 & 39.8 \\
\hline Single & 180 & 54.2 \\
\hline Other* & 20 & 6.0 \\
\hline \multicolumn{3}{|l|}{ Ethnicity } \\
\hline Oromo & 218 & 65.4 \\
\hline Amhara & 51 & 15.4 \\
\hline Dawuro & 34 & 10.2 \\
\hline Other ${ }^{* *}$ & 29 & 8.7 \\
\hline \multicolumn{3}{|l|}{ Religion } \\
\hline Muslim & 189 & 56.9 \\
\hline Orthodox & 110 & 33.2 \\
\hline protestant & 33 & 9.9 \\
\hline \multicolumn{3}{|c|}{ Residence before imprisonment } \\
\hline Rural & 115 & 34.6 \\
\hline Urban & 217 & 65.4 \\
\hline \multicolumn{3}{|c|}{ Monthly income $(\mathrm{ETB})^{\mathrm{a}}$} \\
\hline$<500$ & 110 & 33.1 \\
\hline $501-1000$ & 65 & 19.6 \\
\hline $1001-2500$ & 75 & 22.6 \\
\hline$>2501$ & 82 & 24.7 \\
\hline \multicolumn{3}{|l|}{ Educational status } \\
\hline Not educated & 47 & 14.2 \\
\hline 1-8 Grade & 176 & 53.0 \\
\hline 9-12 Grade & 81 & 24.4 \\
\hline Higher education & 28 & 8.4 \\
\hline \multicolumn{3}{|c|}{ Occupational before incarceration } \\
\hline Employed & 154 & 46.4 \\
\hline Unemployed & 178 & 53.6 \\
\hline \multicolumn{3}{|l|}{ Having children } \\
\hline Yes & 134 & 40.4 \\
\hline No & 198 & 59.6 \\
\hline
\end{tabular}

${ }^{*}$ Widowed, separated, and divorced. ${ }^{* *}$ Kefa, Gurage, Tigre, and Yem. ${ }^{\mathrm{a}}$ Current currency $1 \$=23.35 \mathrm{ETB}$.

Multivariable logistic regression analysis revealed that having history of previous incarceration, having no opportunity for job in the prison, having family history of mental illness, having chronic physical illness, lifetime alcohol use, being in the age group between 21 and 25 years, having poor 
TABLE 2: Clinical factors and Lifetime substance use characteristics of study participants among prisoners in Jimma town prison, South West Ethiopia, June $2017(N=332)$.

\begin{tabular}{|c|c|c|}
\hline Study variables & Frequency $(N)$ & $\begin{array}{c}\text { Percentage } \\
(\%)\end{array}$ \\
\hline \multicolumn{3}{|c|}{ Family member with mental illness } \\
\hline Yes & 57 & 17.2 \\
\hline No & 275 & 82.8 \\
\hline \multicolumn{3}{|c|}{ Chronic physical illness* } \\
\hline Yes & 53 & 16.0 \\
\hline No & 279 & 84.0 \\
\hline \multicolumn{3}{|c|}{ Past mental illness } \\
\hline Yes & 30 & 9.0 \\
\hline No & 302 & 91.0 \\
\hline \multicolumn{3}{|c|}{ Alcohol Use (lifetime) } \\
\hline Yes & 72 & 21.7 \\
\hline No & 260 & 78.3 \\
\hline \multicolumn{3}{|c|}{ Khat Use (lifetime) } \\
\hline Yes & 56 & 16.9 \\
\hline No & 276 & 83.1 \\
\hline \multicolumn{3}{|c|}{ Cigarette smoking (lifetime) } \\
\hline Yes & 152 & 45.8 \\
\hline No & 180 & 54.2 \\
\hline \multicolumn{3}{|c|}{ Cannabis/shisha/ganga use (lifetime) } \\
\hline Yes & 22 & 6.6 \\
\hline No & 310 & 93.4 \\
\hline
\end{tabular}

social support, and thinking life after released from prison is difficult had significant association with depression.

Accordingly, the odds of having depression among prisoners who were previously incarcerated were 3.26 times higher $(\mathrm{AOR}=3.26,95 \% \mathrm{CI}=1.02,10.64)$ compared with those who were not previously incarcerated. The odds of having depression among prisoners who had no job in prison were 4.96 times higher $(\mathrm{AOR}=4.96,95 \% \mathrm{CI}=2.09,11.80)$ than prisoners who had work in the prison. The odds of having depression were 6.05 times more $(\mathrm{AOR}=6.05,95 \%$ $\mathrm{CI}=2.6,13.80)$ among prisoners who had family member with mental illness as compared with prisoners who have no family members with mental illness. Prisoners who had chronic physical illness were 2.87 times $(\mathrm{AOR}=2.87,95 \% \mathrm{CI}$ $=1.29,6.41$ ) more likely to develop depression than prisoners who have no chronic physical illness. Prisoners who were in the age group between 21 and 25 years were 2.04 times more likely $(\mathrm{AOR}=2.04,95 \% \mathrm{CI}=1.06,3.89)$ to develop depression compared with prisoners in the age above 34 years. Prisoners who had poor social support were 2.2 times more likely (AOR $=2.2,95 \% \mathrm{CI}=1.27,3.82$ ) to report depression than prisoners with strong social support. The odds of having depression among prisoners who were lifetime alcohol use were 3.61 times $(\mathrm{AOR}=3.61,95 \% \mathrm{CI}=1.80,7.26)$ than prisoners who did not use alcohol in their lifetime. Prisoners who were thinking life after release from prison is difficult were 2.07 times more likely ( $\mathrm{AOR}=2.07,95 \% \mathrm{CI}=1.2,3.6)$ to develop depression when compared to those not thinking life after released from prison is difficult (Table 4).

\section{Discussion}

This study revealed the overall prevalence of depression among prisoners to be $41.9 \%$. The result is lined with studies carried out in US 43\% [20], Brazil 40\% [15], Nigeria 42.2\% [14], and Ethiopia and Amhara 43.8\% [5]. However, it was higher than the study done in Brazil 9.9\% [15]. In systematic review of 2300 prisoners in western countries the prevalence of depression was $10 \%$ among men and $12 \%$ among women [6], South Africa 10.4\% [11], Iran 29\% [9], and Nigeri 30.8\% [19].

Results of this study showed that history of previous incarceration and depression has significant association. This might be due to prisoners developing depression as a result of repeated exposure for the prison environment [26]. The study done previously showed that prisoners performing work inside the prison were less depressed which is similar to the current result. This might be because they become adjusted to the difficult life of prison and also when they perform income-generating jobs they get income and because of this they become less depressed [21].

Results of this study showed that having family history of mental illness is significant predictors for depression. Previous studies support this result $[21,27]$. This might be due to mental illness having genetic base $[3,27,28]$. From this study there was statistically significant relation between chronic physical illness and depression. The possible reason could be that depression is more commonly encountered in people who have chronic physical illness [28]. This study showed that prisoners who had poor social support were more likely to develop depression. The possible reason could be that depressed prisoners are likely to suffer in many domains of life and appear less likely to adapt to prison or life thereafter.

Results of this study revealed that prisoners aged 21-25 years old were more likely to develop depression than those above the age of 34 years. Previous study done in US [8] is in line with this result. The possible reason could be individual with this age group is more likely to report alcohol and other substance use before incarceration which might lead them to develop depression. Other literatures also reported as depression being more common in this age group [10]. Lifetime alcohol use and being depressed were significantly associated. A study done in Egypt [21] and US [29] was in line with the current result. The possible reason could be that prison is stressful environment which make prisoners distressed [19].

The result of this study showed that those prisoners who think life to be difficult after release from prison were more depressed. The possible reason could be feeling of inadequacy; as the prisoners worry about their future life, they are easily affected by depression [12].

4.1. Strength of the Study. Strength of this study is that the severity of depression in addition to the prevalence is 
TABLE 3: Factors associated with depression by bivariate logistic regression among prisoners in Jimma town prison, South West Ethiopia, June $2017(N=332)$.

\begin{tabular}{|c|c|c|c|c|}
\hline \multirow[b]{2}{*}{ Study variables } & \multicolumn{2}{|c|}{ Depression } & \multirow[b]{2}{*}{ COR $(95 \% \mathrm{CI})$} & \multirow[b]{2}{*}{$p$-value } \\
\hline & $\begin{array}{c}\text { Yes } \\
N(\%) \\
\end{array}$ & $\begin{array}{c}\text { No } \\
N(\%) \\
\end{array}$ & & \\
\hline \multicolumn{5}{|l|}{ Gender } \\
\hline Female & $14(66.7)$ & $7(33.3)$ & $2.97(1.17,7.58)$ & 0.022 \\
\hline Male & $125(40.2)$ & $186(59.8)$ & 1 & \\
\hline \multicolumn{5}{|l|}{ Age (year) } \\
\hline $18-20$ & $29(35.4)$ & $53(64.6)$ & $0.69(0.41,1.17)$ & 0.17 \\
\hline $21-25$ & $43(55.1)$ & $35(44.9)$ & $2.02(1.21,3.38)$ & 0.007 \\
\hline $26-33$ & $36(40.0)$ & $54(60.0)$ & $0.9(0.55,1.47)$ & 0.64 \\
\hline$>34$ & $31(37.8)$ & $51(62.2)$ & 1 & \\
\hline \multicolumn{5}{|l|}{ Marital status } \\
\hline Married & $55(41.8)$ & $77(58.3)$ & 1 & \\
\hline Single & $71(39.4)$ & $109(60.6)$ & $0.805(0.519,1.25)$ & 0.33 \\
\hline Other & $13(65.0)$ & $7(35.0)$ & $2.741(1.06,7.062)$ & 0.037 \\
\hline \multicolumn{5}{|l|}{ Ethnicity } \\
\hline Oromo & $94(43.1)$ & $124(56.9)$ & 1 & \\
\hline Amhara & $22(43.1)$ & $29(56.9)$ & $1.06(0.582,1.943)$ & 0.842 \\
\hline Dawuro & $10(29.4)$ & $24(70.6)$ & $0.546(0.252,1.182)$ & 0.125 \\
\hline Other & $13(44.8)$ & $16(55.2)$ & $1.14(0.53,2.45)$ & 0.735 \\
\hline \multicolumn{5}{|l|}{ Religion } \\
\hline Muslim & $80(42.3)$ & $109(57.7)$ & 1 & \\
\hline Orthodox & $47(42.7)$ & $63(58.1)$ & $1.05(0.66,1.67)$ & 0.82 \\
\hline Protestant & $12(36.4)$ & $21(63.6)$ & $0.774(0.367,1.631)$ & 0.5 \\
\hline \multicolumn{5}{|l|}{ Educational status } \\
\hline Illiterate & $24(17.3)$ & $23(11.9)$ & $0.986(0.414,2.35)$ & 0.974 \\
\hline $1-8$ grade & $68(48.9)$ & $108(56.0)$ & $1.37(0.667,2.821)$ & 0.391 \\
\hline $9-12$ grade & $35(25.2)$ & $46(23.8)$ & $0.828(0.485,1.412)$ & 0.487 \\
\hline Higher education & $12(8.6)$ & $16(8.3)$ & 1 & \\
\hline \multicolumn{5}{|l|}{ Occupation } \\
\hline Unemployed & $76(54.7)$ & $102(52.8)$ & $1.076(0.695,1.667)$ & 0.742 \\
\hline Employed & $63(45.3)$ & $91(47.2)$ & 1 & \\
\hline \multicolumn{5}{|l|}{$\begin{array}{l}\text { Residence before } \\
\text { incarceration }\end{array}$} \\
\hline Rura & $46(40.0)$ & $69(60.0)$ & 1 & \\
\hline Urban & $93(42.9)$ & $124(57.1)$ & $1.125(0.71-1.78)$ & 0.616 \\
\hline \multicolumn{5}{|l|}{ Having children } \\
\hline Yes & $53(38.1)$ & $86(61.9)$ & 1 & \\
\hline No & $81(42.0)$ & $112(58.0)$ & $0.852(0.546,1.331)$ & 0.482 \\
\hline \multicolumn{5}{|l|}{ Previous incarceration } \\
\hline Yes & $23(82.1)$ & $5(17.9)$ & $7.45(2.758-20.152)$ & $<0.001$ \\
\hline No & $116(38.2)$ & $188(61.8)$ & 1 & \\
\hline \multicolumn{5}{|c|}{$\begin{array}{l}\text { Duration of stay in prison (in } \\
\text { month) }\end{array}$} \\
\hline$<4$ & $35(38.5)$ & $56(61.5)$ & 1 & \\
\hline $5-10$ & $38(45.2)$ & $46(54.8)$ & $1.2(0.73-1.98)$ & 0.469 \\
\hline $11-24$ & $37(48.1)$ & $40(51.9)$ & $1.39(0.83-2.31)$ & 0.21 \\
\hline$>25$ & $29(36.2)$ & $51(63.8)$ & $0.73(0.43-1.23)$ & 0.243 \\
\hline
\end{tabular}


TABle 3: Continued.

\begin{tabular}{|c|c|c|c|c|}
\hline \multirow[b]{2}{*}{ Study variables } & \multicolumn{2}{|c|}{ Depression } & \multirow[b]{2}{*}{ COR $(95 \% \mathrm{CI})$} & \multirow[b]{2}{*}{$p$-value } \\
\hline & $\begin{array}{c}\text { Yes } \\
N(\%)\end{array}$ & $\begin{array}{c}\text { No } \\
N(\%)\end{array}$ & & \\
\hline \multicolumn{5}{|c|}{$\begin{array}{l}\text { Thinking life after released } \\
\text { from prison is difficult }\end{array}$} \\
\hline Yes & $77(51.7)$ & $72(48.3)$ & $2.08(1.34-3.25)$ & 0.001 \\
\hline No & $62(33.9)$ & $121(66.1)$ & & \\
\hline \multicolumn{5}{|c|}{ Acceptance of criminality } \\
\hline No & $91(43.3)$ & $119(56.7)$ & $1.179(0.748-1.857)$ & 0.48 \\
\hline Yes & $48(39.3)$ & $74(60.7)$ & 1 & \\
\hline \multicolumn{5}{|l|}{ Criminal type } \\
\hline Robbery & $67(46.5)$ & $77(53.5)$ & 1 & \\
\hline Rape & $8(23.5)$ & $26(76.5)$ & $0.35(0.15,0.83)$ & 0.08 \\
\hline Corruption & $6(27.3)$ & $16(72.7)$ & $0.43(0.16,1.16)$ & 0.90 \\
\hline Murderer & $45(45.0)$ & $55(55.0)$ & $0.94(0.56,1.57)$ & 0.47 \\
\hline Other* & $13(40.6)$ & $19(59.4)$ & $0.78(0.36-1.71)$ & 0.74 \\
\hline \multicolumn{5}{|l|}{ Pray in prison } \\
\hline No & $36(75.0)$ & $12(25.0)$ & $5.27(2.627-10.581)$ & $<0.001$ \\
\hline Yes & $103(36.3)$ & $181(63.7)$ & 1 & \\
\hline \multicolumn{5}{|c|}{ Having work in prison } \\
\hline No & $127(47.2)$ & $142(52.8)$ & $3.8(1.94,7.45)$ & $<0.001$ \\
\hline Yes & $12(19.0)$ & $51(81.0)$ & 1 & \\
\hline \multicolumn{5}{|c|}{ Family with mental illness } \\
\hline Yes & $43(75.4)$ & $14(24.6)$ & $5.73(2.98,10.99)$ & $<0.001$ \\
\hline No & $96(34.9)$ & $179(65.1)$ & 1 & \\
\hline \multicolumn{5}{|c|}{ Chronic physical illness } \\
\hline Yes & $36(67.9)$ & $17(32.1)$ & $3.62(1.94,6.77)$ & $<0.001$ \\
\hline No & $103(36.9)$ & $176(63.1)$ & 1 & \\
\hline \multicolumn{5}{|c|}{ Past mental illness } \\
\hline Yes & $25(83.3)$ & $5(16.7)$ & $8.24(3.07,22.14)$ & $<0.001$ \\
\hline No & $114(37.7)$ & $188(62.3)$ & 1 & \\
\hline \multicolumn{5}{|c|}{ Level of social support } \\
\hline Strong & $13(26.0)$ & $37(74.0)$ & 1 & \\
\hline Moderate & $38(33.6)$ & $75(66.4)$ & $0.157(0.09-0.277)$ & $<0.001$ \\
\hline Poor support & $88(52.1)$ & $81(47.9)$ & $16(9.13-28.27)$ & $<0.001$ \\
\hline \multicolumn{5}{|c|}{ Alcohol use (life time) } \\
\hline Yes & $50(69.4)$ & $22(30.6)$ & $4.37(2.49,7.67)$ & $<0.001$ \\
\hline No & $89(34.2)$ & $171(65.8)$ & 1 & \\
\hline \multicolumn{5}{|c|}{ Khat use (lifetime) } \\
\hline Yes & $82(53.9)$ & $70(46.1)$ & $2.53(1.61,3.95)$ & $<0.001$ \\
\hline No & $57(31.7)$ & $123(68.3)$ & 1 & \\
\hline \multicolumn{5}{|c|}{ Cigarette smoking (lifetime) } \\
\hline Yes & $37(66.1)$ & $19(33.9)$ & $3.32(1.81,6.08)$ & $<0.001$ \\
\hline No & $102(37.0)$ & $174(63.0)$ & 1 & \\
\hline \multicolumn{5}{|c|}{$\begin{array}{l}\text { Cannabis/shisha/ganja } \\
\text { use(life time) }\end{array}$} \\
\hline Yes & $17(81.0)$ & $4(19.0)$ & $6.58(2.16,20.03)$ & 0.001 \\
\hline No & $122(39.2)$ & $189(60.8)$ & 1 & \\
\hline
\end{tabular}

* Illegal trading, arson, related to government, and illegal marriage. 
TABLE 4: Factors associated with depression by multivariable logistic regression among prisoners in Jimma town prison, South West Ethiopia, June $2017(N=332)$.

\begin{tabular}{|c|c|c|c|c|}
\hline \multirow[b]{2}{*}{ Study variables } & \multicolumn{2}{|c|}{ Depression } & \multirow[b]{2}{*}{$\operatorname{AOR}(95 \% \mathrm{CI})$} & \multirow[b]{2}{*}{$p$-value } \\
\hline & $\begin{array}{c}\text { Yes } \\
N(\%)\end{array}$ & $\begin{array}{c}\text { No } \\
N(\%) \\
\end{array}$ & & \\
\hline \multicolumn{5}{|l|}{ Gender } \\
\hline Female & $14(66.7)$ & $7(33.3)$ & $2.35(0.76,7.25)$ & 0.13 \\
\hline Male & $125(40.2)$ & $186(59.8)$ & 1 & \\
\hline \multicolumn{5}{|l|}{ Age (year) } \\
\hline $18-20$ & $29(35.4)$ & $53(64.6)$ & $1.04(0.45,2.40)$ & 0.93 \\
\hline $21-25$ & $43(55.1)$ & $35(44.9)$ & $2.04(1.06,3.89)$ & 0.03 \\
\hline $26-33$ & $36(40.0)$ & $54(60.0)$ & $0.93(0.47,1.81)$ & 0.83 \\
\hline$>34$ & $31(37.8)$ & $51(62.2)$ & 1 & \\
\hline \multicolumn{5}{|c|}{ Previous incarceration } \\
\hline Yes & $23(82.1)$ & $5(17.9)$ & $3.26(1.02,10.64)$ & 0.05 \\
\hline No & $116(38.2)$ & $188(61.8)$ & 1 & \\
\hline \multicolumn{5}{|c|}{$\begin{array}{l}\text { Thinking life after released } \\
\text { from prison is difficult }\end{array}$} \\
\hline Yes & $77(51.7)$ & $72(48.3)$ & $2.07(1.2,3.6)$ & 0.009 \\
\hline No & $62(33.9)$ & $121(66.1)$ & 1 & \\
\hline \multicolumn{5}{|l|}{ Criminal type } \\
\hline Robbery & $67(46.5)$ & $77(53.5)$ & 1 & \\
\hline Rape & $8(23.5)$ & $26(76.5)$ & $0.40(0.14,1.12)$ & 0.08 \\
\hline Corruption & $6(27.3)$ & $16(72.7)$ & $0.93(0.28,3.02)$ & 0.90 \\
\hline Murderer & $45(45.0)$ & $55(55.0)$ & $1.26(0.66,2.40)$ & 0.47 \\
\hline Other* & $13(40.6)$ & $19(59.4)$ & $0.85(0.33,2.18)$ & 0.74 \\
\hline \multicolumn{5}{|c|}{ Having work in prison } \\
\hline No & $127(47.2)$ & $142(52.8)$ & $4.96(2.09,11.80)$ & $<0.001$ \\
\hline Yes & $12(19.0)$ & $51(81.0)$ & 1 & \\
\hline \multicolumn{5}{|c|}{ Family with mental illness } \\
\hline Yes & $43(75.4)$ & $14(24.6)$ & $6.05(2.60,13.80)$ & $<0.001$ \\
\hline No & $96(34.9)$ & $179(65.1)$ & 1 & \\
\hline \multicolumn{5}{|c|}{ Chronic physical illness } \\
\hline Yes & $36(67.9)$ & $17(32.1)$ & $2.87(1.29,6.41)$ & 0.01 \\
\hline No & $103(36.9)$ & $176(63.1)$ & 1 & \\
\hline \multicolumn{5}{|c|}{ Past mental illness } \\
\hline Yes & $25(83.3)$ & $5(16.7)$ & $2.87(0.84,9.80)$ & 0.09 \\
\hline No & $114(37.7)$ & $188(62.3)$ & 1 & \\
\hline \multicolumn{5}{|c|}{ Level of social support } \\
\hline Strong & $13(26.0)$ & $37(74.0)$ & 1 & \\
\hline Moderate & $38(33.6)$ & $75(66.4)$ & $1.07(0.43,2.66)$ & 0.88 \\
\hline Poor support & $88(52.1)$ & $81(47.9)$ & $2.20(1.27,3.82)$ & 0.005 \\
\hline \multicolumn{5}{|c|}{ Alcohol use (life time) } \\
\hline Yes & $50(69.4)$ & $22(30.6)$ & $3.61(1.80,7.26)$ & $<0.001$ \\
\hline No & $89(34.2)$ & $171(65.8)$ & 1 & \\
\hline \multicolumn{5}{|c|}{ Khat use (lifetime) } \\
\hline Yes & $82(53.9)$ & $70(46.1)$ & $1.71(0.95,3.07)$ & 0.07 \\
\hline No & $57(31.7)$ & $123(68.3)$ & 1 & \\
\hline \multicolumn{5}{|c|}{ Cigarette smoking (lifetime) } \\
\hline Yes & $37(66.1)$ & $19(33.9)$ & $1.78(0.77,4.10)$ & 0.17 \\
\hline No & $102(37.0)$ & $174(63.0)$ & 1 & \\
\hline
\end{tabular}


TABLE 4: Continued.

\begin{tabular}{lcccc}
\hline Study variables & Yes & Depression & AOR $(95 \% \mathrm{CI})$ & $p$-value \\
& $N(\%)$ & $N(\%)$ & & \\
\hline $\begin{array}{l}\text { Cannabis/shisha/ganja use } \\
\text { (life time) }\end{array}$ & & & & \\
$\quad$ Yes & $17(81.0)$ & $4(19.0)$ & $2.08(0.47,9.24)$ & 0.33 \\
No & $122(39.2)$ & $189(60.8)$ & 1 & \\
\hline
\end{tabular}

* Illegal trading, arson, related to government, and illegal marriage.

determined. In addition, the tool we used is standardized and internationally recognized screening tool is used with high reliability to screen depression regardless of population characteristics.

4.2. Limitations. The study however could suffer from the following limitations. This study was cross-sectional study design; it did not allow establishing a temporal relationship between depression and associated factors. The study was institution based which could limit its generalizability to normal population and clinical setting. The other limitation of the data is regarding depression-related questions. Recall bias regarding lifetime substance use and question to assess factors like belief that life after prison will be difficult, acceptance of crime done, and chronic illness were asked by single generated questions which have no internationalized cutoff point or no Likert scale.

The areas yet to be studied in this population are socioeconomic and prison environment characteristics of respondents like marital status, duration of stay in prison, and lifetime substance use like cigarette, khat, and cannabis use have no association with depression. The other important things that are yet to be studied which we saw during this study but are not included in our study are life style conditions of prisoners in prison like food, place of sleep, recreational activity, and bullying. There are other areas that need investigation.

\section{Conclusion and Recommendation}

In conclusion, depression among prisoners was found to be significantly high. Prisoners who had strong social support and performing work in prison were less likely to have depression while those who had previous incarceration, had family history of mental illness, had chronic physical illness, had lifetime alcohol use, thought life after release from prison is difficult, and were between the age of 21 and 25 years were more likely to have depression. Routine screening and availing treatment in the prison may be of great importance. Future studies investigating the negative consequence of depression among prisoners might be relevant. Interventional studies to identify effective interventions modalities for depression among prisoners might also be relevant.

\section{Conflicts of Interest}

The authors declared no conflicts of interest.

\section{Authors' Contributions}

Zakir Abdu initiated the research, wrote the proposal, did data analysis, and wrote the manuscript. Mubarek Abera, Workinesh Tessema, Teshome Kabeta, and Lamessa Dube provided feedback and supervised the development of the proposal and the manuscript. All authors read and approved the final manuscript.

\section{Acknowledgments}

The authors are grateful to Jimma University and Mettu University for their support. They also thank all the data collectors and study participants who have kindly given them the necessary information.

\section{References}

[1] World Health Organization, Making Mental Health a Global Development Priority, To coincide with the World Bank Group/ IMF Spring Meeting, World Health Organization, Washington, DC, USA, 2016, http://www.who.int/mental_health/WB.

[2] E. Halliwell, L. Main, and C. Richardson, The Fundamental Facts; The Latest Facts And Figures on Mental Health, 2007, https://www.mentalhealth.org.uk/sites/default/files/.

[3] K. P. S. Kumar, S. Srivastava, S. Paswan, and A. S. Dutta, "Depression - symptoms , causes , medications and therapies," The Pharmaceutical Journal, vol. 1, no. 3, pp. 37-51, 2012.

[4] World Health Organization, ECOSOC meeting "Addressing noncommunicable diseases and mental health: major challenges to sustainable development in the 21st century" Discussing Paper "Mental health, poverty a nd development", 2009, http://www.who.int/un-collaboration/health/ecosoc/en/.

[5] T. K. Beyen, A. F. Dadi, B. A. Dachew, N. Y. Muluneh, and T. A. Bisetegn, "More than eight in every nineteen inmates were living with depression at prisons of Northwest Amhara Regional State, Ethiopia, a cross sectional study design," BMC Psychiatry, vol. 17, no. 31, pp. 1-9, 2017.

[6] S. Fazel and J. Danesh, "Serious mental disorder in 23000 prisoners: A systematic review of 62 surveys," The Lancet, vol. 359, no. 9306, pp. 545-550, 2002.

[7] S. Fazel and K. Seewald, "Severe mental illness in 33588 prisoners worldwide: Systematic review and meta-regression analysis," The British Journal of Psychiatry, vol. 200, no. 5, pp. 364-373, 2012.

[8] D. J. James and L. E. Glaze, Mental Health Problems of Prison and Jail Inmates, U.S. Department of Justice, Office of Justice Programs, Bureau of Justice Statistics, 2006. 
[9] S. M. Assadi, M. Noroozian, M. Pakravannejad et al., "Psychiatric morbidity among sentenced prisoners: Prevalence study in Iran," The British Journal of Psychiatry, vol. 188, pp. 159-164, 2006.

[10] F. O. Fatoye, G. K. Fatoye, A. O. Oyebanji, and A. S. Ogunro, "Psychological characteristics as correlates of emotional burden in incarcerated offenders in Nigeria," East African Medical Journal, vol. 83, no. 10, pp. 545-552, 2006.

[11] S. Naidoo and D. L. Mkize, "Prevalence of mental disorders in a prison population in Durban, South Africa," South African Journal of Psychiatry, vol. 15, no. 1, pp. 30-35, 2012.

[12] E. M. Ibrahim, Z. A. Halim, E. A. Wahab, and N. A. Sabry, "Psychiatric morbidity among prisoners in Egypt," World Journal of Medical Sciences, vol. 11, no. 2, pp. 228-232, 2014.

[13] U. Nwaopara and P. Stanley, "Prevalence of depression in Port Harcourt Prison," South African Journal of Psychiatry, vol. 18, no. 6, Article ID 1000340, 2015.

[14] U. Nwaopara and P. Stanley, "Prevalence of Depression in Port Harcourt Prison," Journal of Psychiatry, vol. 18, no. 6, 2015.

[15] S. B. Andreoli, M. M. Dos Santos, M. I. Quintana et al., "Prevalence of mental disorders among prisoners in the state of Sao Paulo, Brazil," PLoS ONE, vol. 9, no. 2, Article ID e88836, 2014.

[16] P. Constantino, S. G. de Assis, and L. W. Pinto, "The impact of prisons on the mental health of prisoners in the state of Rio de Janeiro, Brazil," Ciencia \& Saúde Coletiva, vol. 21, no. 7, pp. 2089-2100, 2016.

[17] A. Ahmad and N. H. Mazlan, "Stress and depression: a comparison study between men and women inmates in peninsular Malaysia," International Journal of Humanities and Social Science, vol. 4, no. 2, pp. 153-160, 2014.

[18] P. V. Datta, M. N. S. V. V. R. M. Vijaya, I. V. V. Krishna, B. S. Bai, M. T. Sharon, and S. Ramam, "Prevalence of depression and assessment of its severity among prisoners of central prison, rajahmundry," Indo American Journal of Pharmaceutical Research, vol. 5, no. 9, pp. 2893-2898, 2015.

[19] A. Y. Armiya'u, A. Obembe, M. D. Audu, and T. O. Afolaranmi, "Prevalence of psychiatric morbidity among inmates in Jos maximum security prison," Open Journal of Psychiatry, vol. 03, no. 01, pp. 12-17, 2013.

[20] T. L. Rowell, J. Draine, and E. Wu, "Depression in a random sample of incarcerated African-American men," Psychiatric Services, vol. 62, no. 1, pp. 103-104, 2011.

[21] A. El-Gilany, M. Khater, Z. Gomaa, E. Hussein, and I. Hamdy, "Psychiatric disorders among prisoners: A national study in Egypt," East Asian Archives of Psychiatry, vol. 26, no. 1, pp. 3038, 2016.

[22] N. Uche and S. Princewill, "Clinical factors as predictors of depression in a Nigerian prison population," South African Journal of Psychiatry, vol. 19, no. 1, Article ID 1000345, 2016.

[23] M. M. Gharavi, H. Kashani, M. Lotfi, and M. Borhani, "Comparison of depression, anxiety, general mental health and selfesteem among prisoners in consultancy and ordinary wings," Journal of Mental Health, vol. 17, no. 12, pp. 52-57, 2015.

[24] H. Bøen, O. S. Dalgard, and E. Bjertness, "The importance of social support in the associations between psychological distress and somatic health problems and socio-economic factors among older adults living at home: a cross sectional study," BMC Geriatrics, vol. 12, article 27, pp. 1-12, 2012.

[25] T. Abiola, O. Udofia, and M. Zakari, "Psychometric Properties of the 3-Item Oslo Social Support Scale among Clinical Students of Bayero University Kano , Nigeria," Malaysian Journal of Psychiatry, vol. 22, no. 2, pp. 23-27, 2013.
[26] C. Armour, "Mental health in prison: a trauma perspective on importation and deprivation," International Journal of Criminology and Sociological Theory, vol. 5, no. 2, pp. 886-894, 2012.

[27] B. J. Sadock, Synopsis of Psychiatry Behavioral Sciences/Clinical Psychiatry, 11 edition, 2013, http://www.lww.com/.

[28] BearingPoint,. In: Atos Healthcare \& DSP EBM Depression, 2010, http://www.welfare.ie.

[29] R. C. Holliday, R. L. Braithwaite, E. Yancey et al., "Substance Use correlates of depression among African American male inmates," Journal of Health Care for the Poor and Underserved, vol. 27, no. 2, pp. 181-193, 2016. 


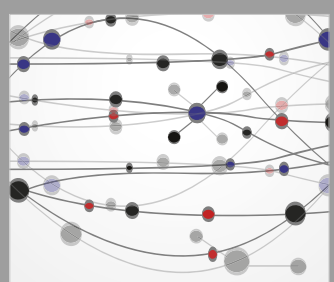

The Scientific World Journal
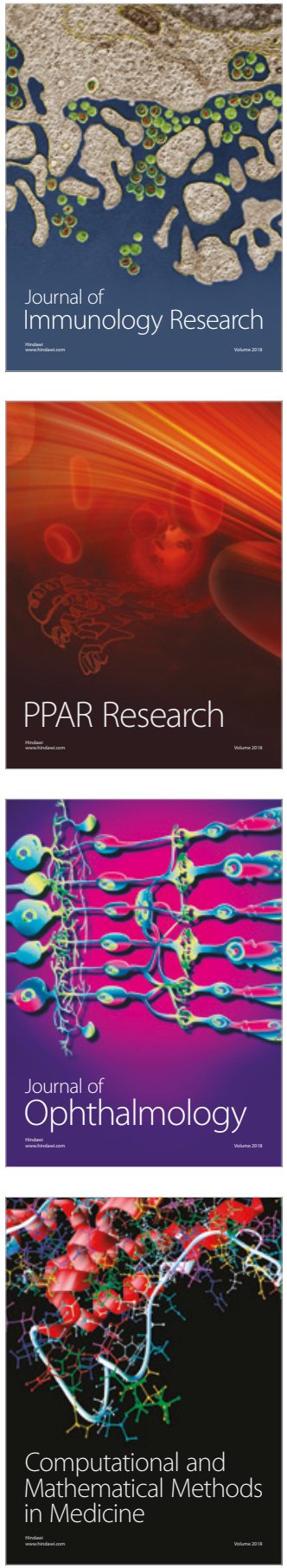

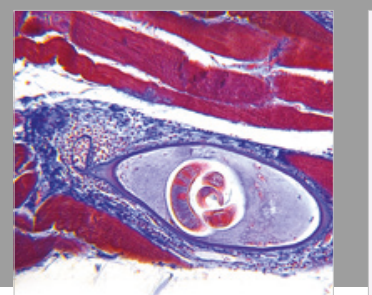

Gastroenterology Research and Practice

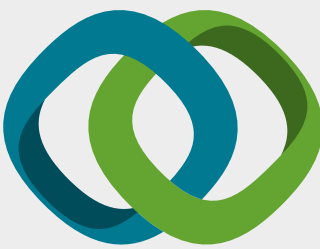

\section{Hindawi}

Submit your manuscripts at

www.hindawi.com
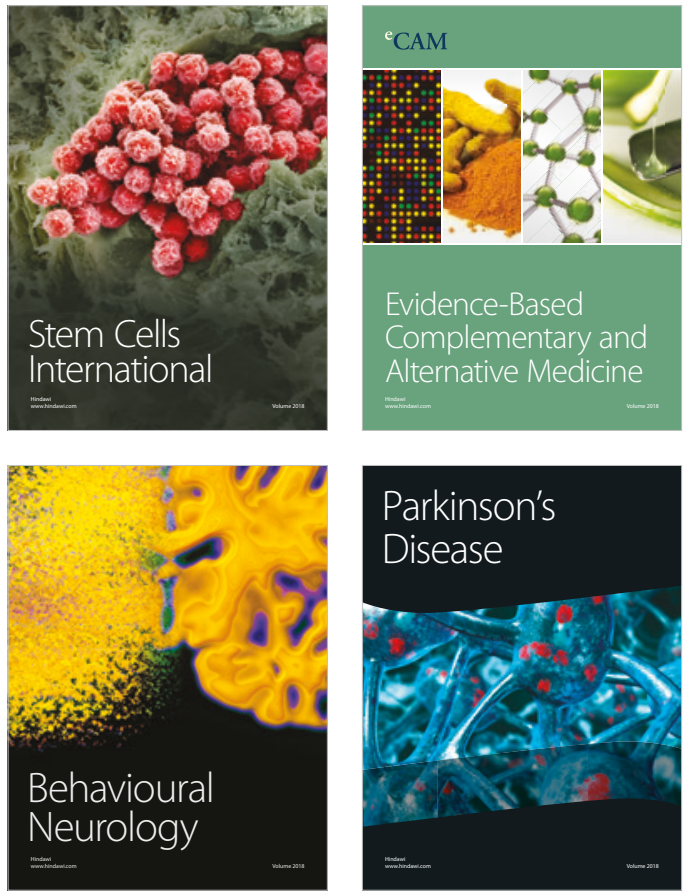

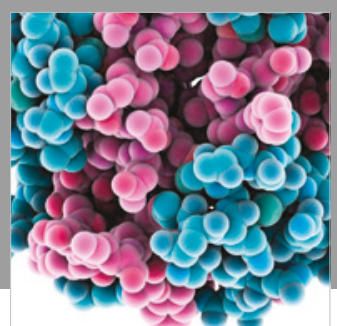

ournal of

Diabetes Research

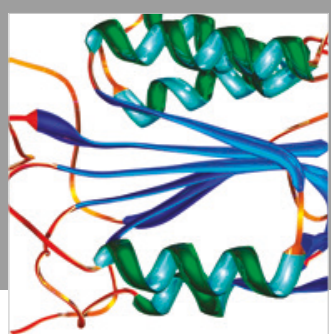

Disease Markers
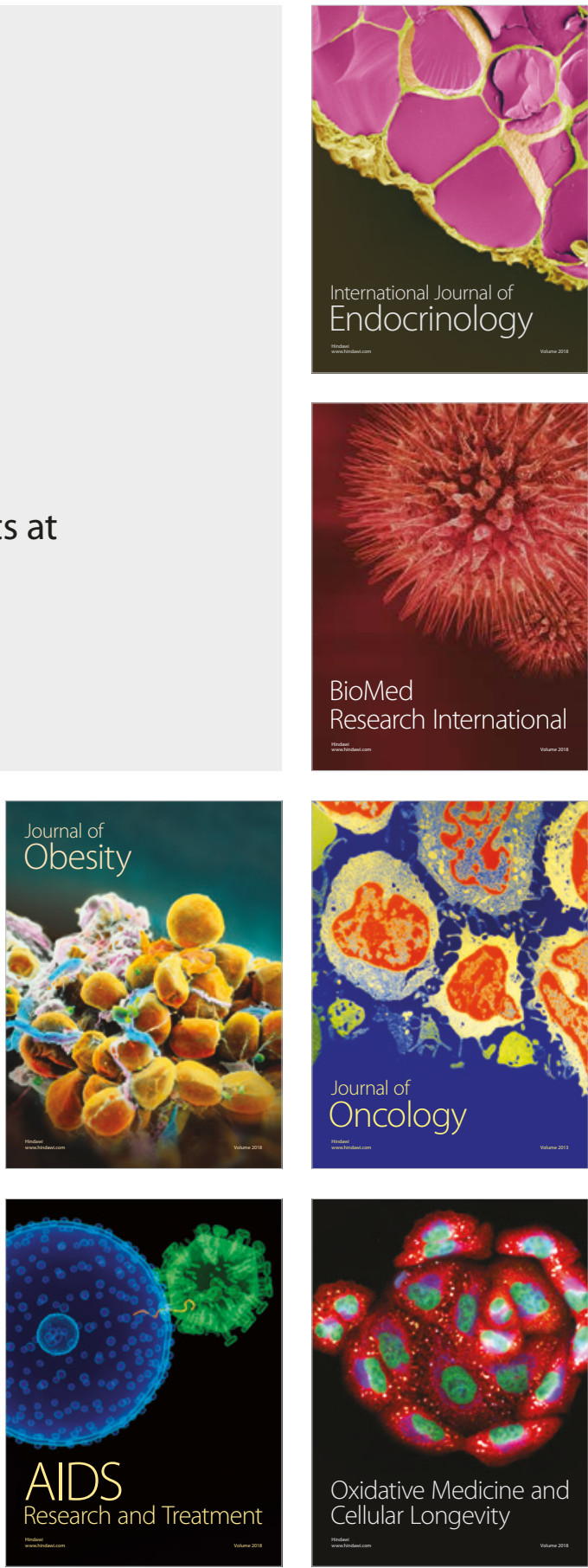